\section{Highly Efficient Phosphate Diester \\ Transesterification by a Calix[4]arene-Based Dinuclear Zinc(II) Catalyst}

Peter Molenveld, Susan Kapsabelis,

Johan F. J. Engbersen,* and David N. Reinhoudt*

\section{Laboratory of Supramolecular Chemistry and Technology University of Twente, P.O. Box 217 7500 AE Enschede, The Netherlands \\ Received November 8, 1996}

Various enzymes, ${ }^{1}$ including P1 nuclease, DNA polymerase I, phospholipase $\mathrm{C}$, and alkaline phosphatase, use the synergic action of two metal centers for the hydrolytic cleavage of phosphate ester bonds. Several research groups have taken the challenge to mimic this process with relatively simple model compounds in which two metal centers have been linked by a spacer group (i.e., $\mathrm{Co}$ (III) by $\mathrm{Chin}^{2,3}$ and Czarnik, $4,5 \mathrm{Cu}$ (II) by Chin, ${ }^{6,7} \mathrm{Zn}(\mathrm{II})$ by Breslow, ${ }^{8}$ Kimura, ${ }^{9}$ and Komiyama, ${ }^{10}$ or lanthanide(III) by Schneider $\left.{ }^{11}\right)$. Although occasionally substantial rate accelerations for phosphate ester hydrolysis have been observed, low substrate binding and lack of turnover are general problems encountered with simple model systems. Calix [4]arenes ${ }^{12-14}$ have been recognized for many years as very suitable building blocks for the construction of multifunctional enzyme models, ${ }^{12,15,16}$ because of the possibility of spatial preorganization of catalytic groups and substrate binding sites. However, although many examples of calix[4]arene-based supramolecular receptors are known, ${ }^{13,14}$ the only example of a calix [4]arene-based enzyme model ${ }^{17}$ has been reported by Mandolini et al., ${ }^{16}$ who showed that a calix[4]arene modified at the lower rim with a crown ether $\mathrm{Ba}(\mathrm{II})$ complex exhibits transacylase activity.

In this paper we present calix[4]arene 1, functionalized with two $\mathrm{Zn}$ (II) centers at the distal positions of the upper rim, as the first example of a dinuclear complex which shows both strong binding to a phosphate diester substrate and high catalytic activity. The presence of $0.48 \mathrm{mM}$ of 1 induces a 23000 -fold rate enhancement in the catalytic cyclization of the RNA model substrate 2-(hydroxypropyl)-p-nitrophenyl phosphate (HPNP, ${ }^{18}$ $\left.\mathrm{pH} 7,25^{\circ} \mathrm{C}\right)$. This is the largest catalytic rate acceleration

(1) For recent reviews, see: (a) Sträter, N.; Lipscomb, W. N.; Klabunde, T,; Krebs, B. Angew. Chem., Int. Ed. Engl. 1996, 35, 2024. (b) Wilcox, D. E. Chem. Rev. 1996, 96, 2435.

(2) Williams, N. H.; Chin, J. J. Chem. Soc., Chem. Commun. 1996, 131

(3) Wahnon, D.; Lebuis, A.-M.; Chin, J. Angew. Chem., Int. Ed. Engl. $1995,34,2412$

(4) Vance, D. H.; Czarnik, A. W. J. Am. Chem. Soc. 1993, 115, 12165 (5) Chung, Y.; Akkaya, E. U.; Venkatachalam, T, K.; Czarnik, A. W. Tetrahedron Lett. 1990, 31, 5413

(6) Young, M. J.; Chin, J. J. Am. Chem. Soc. 1995, H7, 10577. 32,1633 .

(8) Chapman, W. H., Jr.; Breslow, R. J. Am. Chem. Soc. 1995, 1J7, 5462.

(9) Koike, T.; Inoue, M.; Kimura, E.; Shiro, M. J. Am. Chem. Soc. 1996 $118,3091$.

(10) Yashiro, M.; Ishikubo, A.; Komiyama, M. J. Chem. Soc., Chem. Commun. 1995, 1793.

(11) Ragunathan, K. G.; Schneider, H.-J. Angew. Chem., Int. Ed. Engl. $1996,35,1219$

(12) Gutsche, C. D. Calixarenes; The Royal Society of Chemistry: Cambridge, England, 1989

(13) Böhmer, V. Angew, Chem., Int. Ed. Engl. 1995, 34, 713.

(14) Takeshita, M.; Shinkai, S. Bull. Chem. Soc. Jpn. 1995, 68, 1088

(15) Atwood, J. L.; Orr, G. W.; Robinson, K. D.; Hamada, F. Supramol Chem. 1993, 2, 309 .

(16) Cacciapaglia, R.; Casnati, A.; Mandolini, L.; Ungaro, R. J. Am Chem. Soc. 1992, 114, 10956.

(17) $p$-Sulfonatocalix[6]arenes (ref 17a) and $p$-(carboxyethyl)calix $[n]$ arenes $(n=5-8$, ref $17 \mathrm{~b}$ ) have shown to be catalytically active in the acid-catalyzed hydration of 1-benzyl-1,4-dihydronicotinamide: (a) Shinkai, S.; Mori, S.; Koreishi, H.; Tsubaki, T.; Manabe, O. J. Am. Chem. Soc, 1986, I08, 2409. (b) Gutsche, C. D.; Alam, I. Tetrahedron 1988, $44,4689$.

(18) Brown, D. M.; Usher, D. A. J. Chem. Soc. 1965, 6558 .

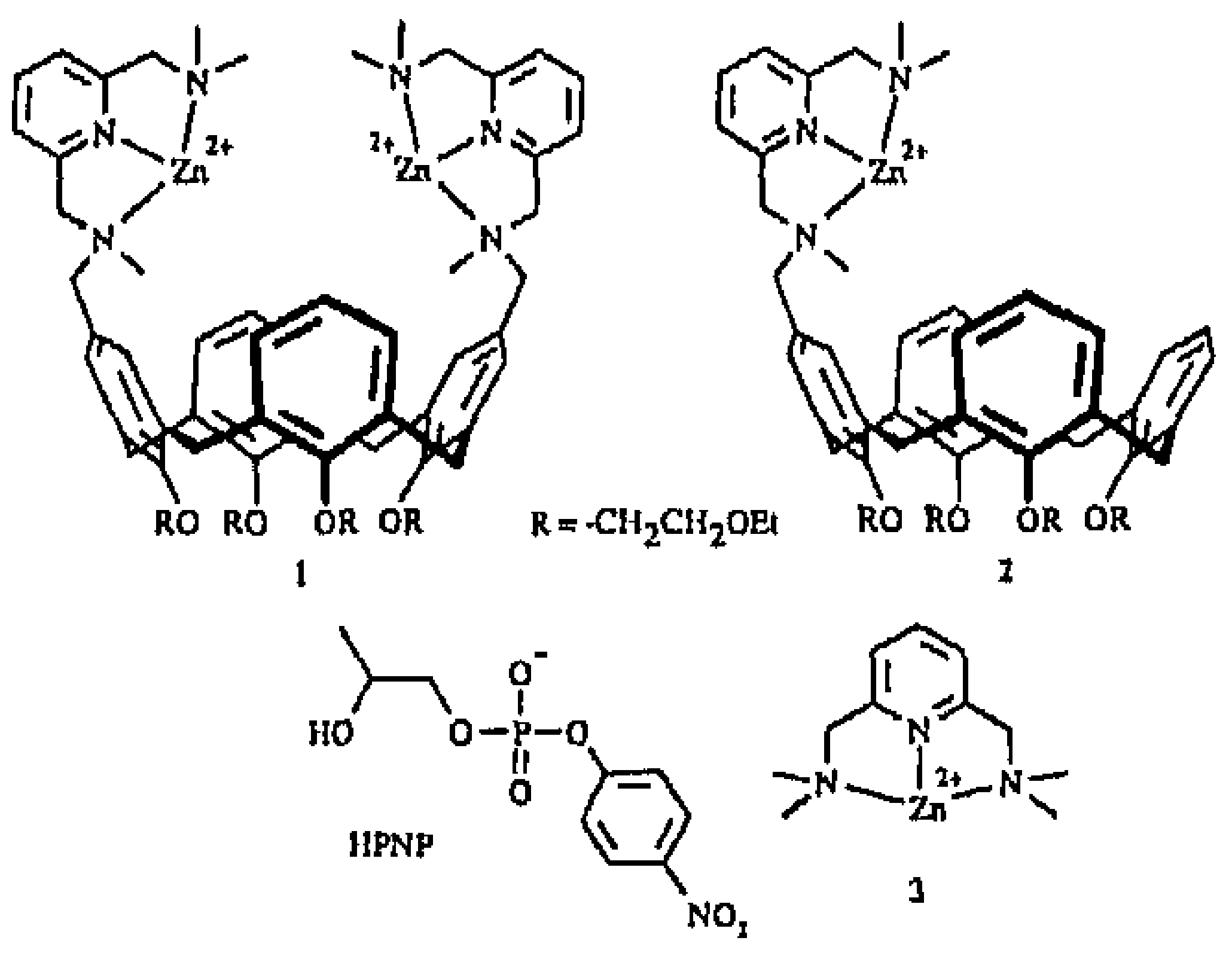

reported for nuclease mimics using this substrate. Comparison of 1 with monofunctionalized calix[4]arene 2 and reference pyridine complex 3 shows that the high catalytic activity of 1 can be attributed to a favorable contribution of the calix[4]arene moiety in substrate binding and catalytic synergic action of the two $\mathrm{Zn}$ (II) centers.

Scheme 1. Synthesis of a Calix[4]arene-Based Dimeric Ligand $\left(\mathrm{R}=\mathrm{CH}_{2} \mathrm{CH}_{2} \mathrm{OEt}\right)^{a}$

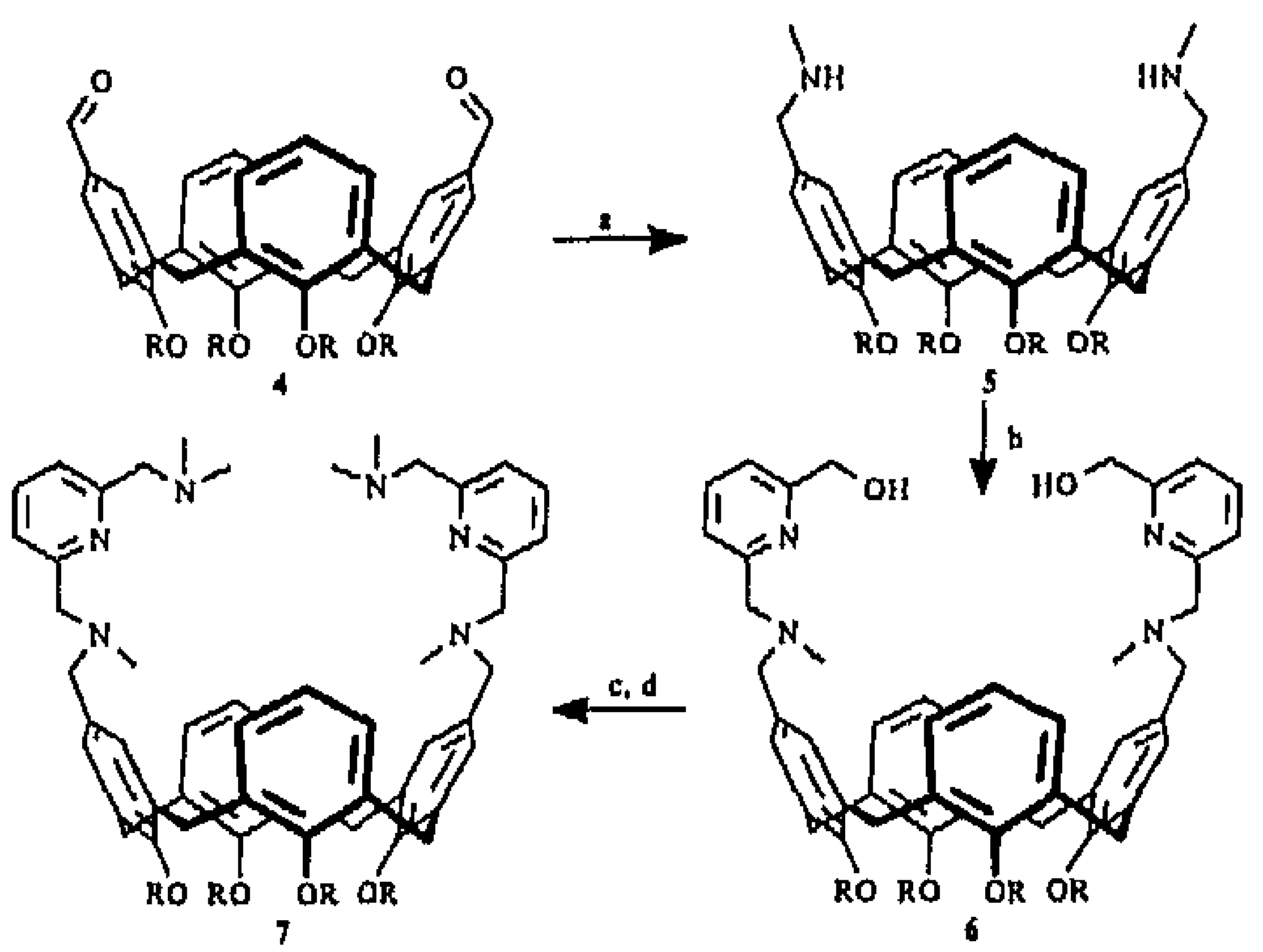

"Key: $33 \% \mathrm{MeNH}_{2}$ in EtOH, $\mathrm{H}_{2}, 10 \% \mathrm{Pd} / \mathrm{C}, 71 \%$; (b) 2-(bromomethyl)-6-(hydroxymethyl)pyridine, ${ }^{20} \mathrm{~K}_{2} \mathrm{CO}_{3}, \mathrm{CH}_{3} \mathrm{CN}, 64 \%$; (c) $\mathrm{SOCl}_{2}$ $\mathrm{CH}_{2} \mathrm{Cl}_{2}, 100 \%$; (d) $\mathrm{Me}_{2} \mathrm{NH} \cdot \mathrm{HCl}, \mathrm{K}_{2} \mathrm{CO}_{3}, \mathrm{CH}_{3} \mathrm{CN}, 65 \%$.

The calix[4]arene-based dimeric ligand 7 was prepared stepwise from diformyltetrakis(ethoxyethyl)calix [4]arene $4^{19}$ and 2-(bromomethyl)-6-(hydroxymethyl)pyridine ${ }^{20}$ according to Scheme 1. The monomeric ligand was prepared analogously, starting from monoformyltetrakis(ethoxyethyl)calix [4]arene, ${ }^{19}$ and the ligand of reference complex 3 was obtained by reaction of bis(bromomethyl)pyridine ${ }^{20}$ with dimethylamine. The corresponding $\mathrm{Zn}(\mathrm{II})$ complexes $(1-3)$ were generated in situ at $0.48 \mathrm{mM}$ in acetonitrile/20 mM HEPES buffer $1: 1(\mathrm{v} / \mathrm{v})$ at 25 ${ }^{\circ} \mathrm{C}$, the reaction conditions for the catalysis experiments. ${ }^{21}$ The association constants for $\mathrm{Zn}$ (II) complexation were determined by UV spectrometry and are $c a .1 \times 10^{5} \mathrm{M}^{-1}$, which implies that under the reaction conditions $85 \%$ of the $\mathrm{Zn}(\mathrm{II})$ is bound to the (aminomethyl)pyridine ligands. ${ }^{22}$

19) Arduini, A.; Fanni, S.; Manfredi, G.; Pochini, A.; Ungaro, R.; Sicuri, A. R.; Ugozzoli, F. J. Org. Chem. 1995, 60, 1448 .

(20) Newcomb, M.; Timko, J. M.; Walba, D. M.; Cram, D. J. J. Am. Chem. Soc. 1977, 99, 6392.

(21) In a typical kinetic experiment, the ligand $7(20 \mu \mathrm{L}, 50 \mathrm{mM})$ and the metal perchlorate $(40 \mu \mathrm{L}, 50 \mathrm{mM})$ were added to $2 \mathrm{~mL}$ of acetonitrile/ $20 \mathrm{mM}$ HEPES $1: 1(\mathrm{v} / \mathrm{v})$ at $25^{\circ} \mathrm{C}$. After a couple of minutes equilibration time, HPNP ${ }^{18}(4 \mu \mathrm{L}, 100 \mathrm{mM})$ was injected into the cuvette. The observed first-order rate constant $\mathrm{Hos}^{-1}\left(\mathrm{~s}^{-1}\right)$ was calculated with the extincti method $<5 \%$ conversion)

(22) All solutions remained clear during the time of the kinetic experiments. In the absence of ligand, precipitation of polymeric $\mathrm{Zn}$ (II) hydroxide took place. 


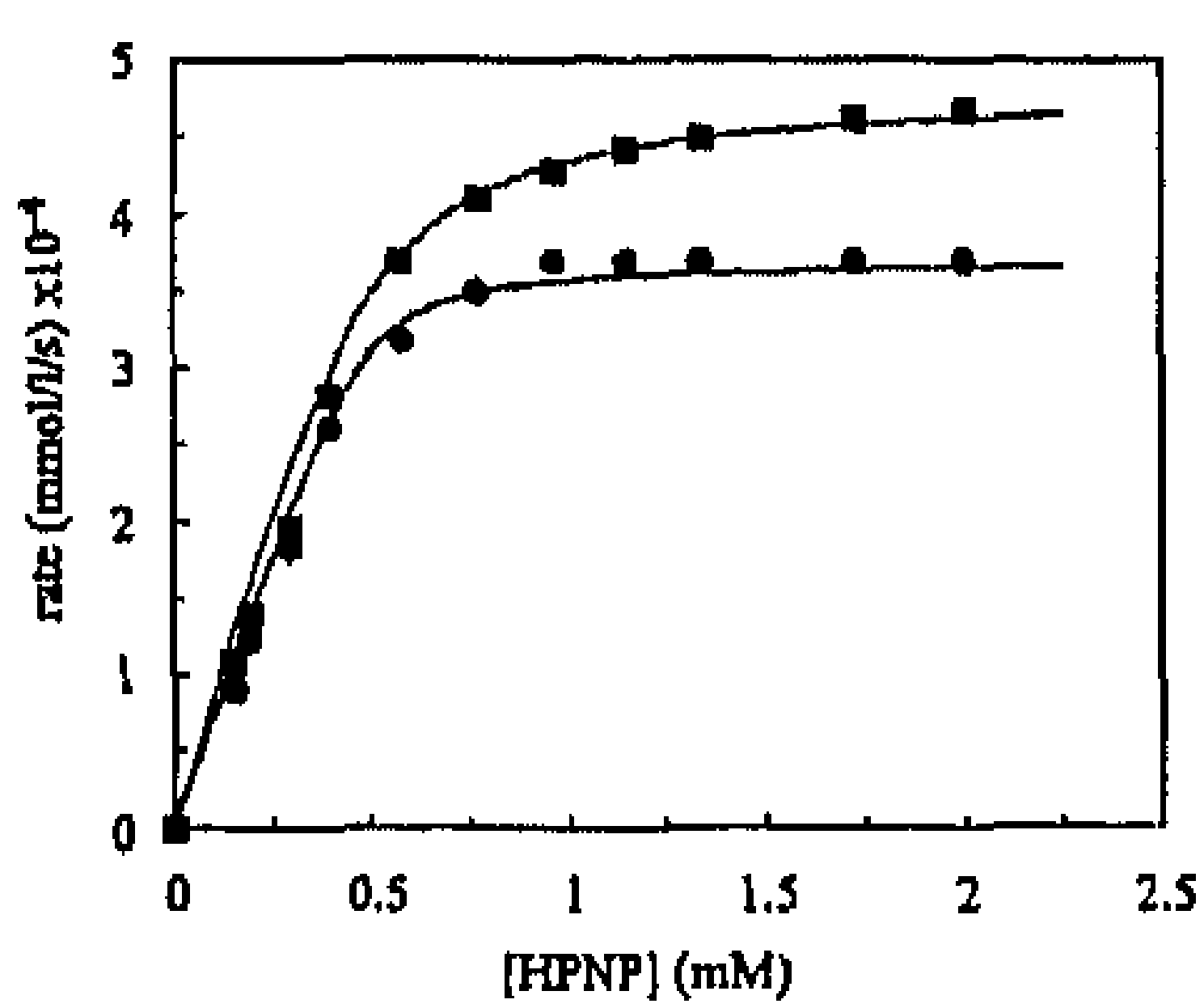

Figure 1. Dependency of the transesterification rate catalyzed by $\mathbf{1}$, on HPNP concentration at $\mathrm{pH} 7.0(\bullet)$ and $7.4(\mathbb{E})([1]=0.48 \mathrm{mM}$, acetonitrile $/ 20 \mathrm{mM}$ HEPES $\left.1: 1(\mathrm{v} / \mathrm{v}), 25^{\circ} \mathrm{C}\right)$.

The catalytic activities of the $\mathrm{Zn}$ (II) complexes toward transesterification of HPNP were studied in the $\mathrm{pH}$ range of $6.8-8.2$ of the aqueous buffer portion of the reaction mixture. ${ }^{21}$ In the absence of metallocatalysts, HPNP reacts extremely slowly; the initial rate at $\mathrm{pH} 7.0$ indicates a half-life for the $p$-nitrophenol release of approximately 300 days $\left(k_{\mathrm{absd}}=2.7\right.$ $\left.\times 10^{-8} \mathrm{~s}^{-1}\right)$. However, the reaction rate increases dramatically (23 000 times) upon the addition of $0.48 \mathrm{mM}$ of 1 to the solution (half-life $18 \mathrm{~min}, k_{\text {obsd }}=6.3 \times 10^{-4} \mathrm{~s}^{-1}$ ). ${ }^{23}$ In a separate experiment using a 4-fold excess of HPNP, 1 shows turnover without significant loss of activity during completion of the reaction, which demonstrates that no product inhibition occurs. The catalytic activity of the mononuclear calix[4]arene $\mathrm{Zn}$ (II) complex 2 is 50 times lower than that of 1 , emphasizing the importance of synergism of the two $\mathrm{Zn}$ (II) centers in 1. The fact that mononuclear calix[4]arene complex 2 is still 6 times more active than reference complex 3 indicates that the calix[4]arene moiety contributes to the catalysis, probably by enhancing the formation of the catalyst-substrate complex.

Assuming product formation by a two-step pathway viz., (i) rapid pre-equilibration of the catalyst--substrate complex $\left(K_{\text {assn }}\right)$ followed by (ii) rate-determining conversion of the substrate within the complex $\left(k_{\mathrm{cat}}\right)$, saturation kinetics must be observed when binding of the substrate to the catalyst is sufficiently high. Measurement of the rate as a function of substrate concentration (Figure 1) reveals that catalyst 1 has a very high affinity for the substrate. At pH 7.0, already $80 \%$ of the substrate is bound to catalyst 1 at equimolar concentrations $(0.48 \mathrm{mM})$, and saturation is readily reached at higher substrate concentration. Fitting of the experimental data according to steady state pseudofirst-order kinetics gave values for $K_{\text {nssn }}$ of $5.5 \times 10^{4} \mathrm{M}^{-1}$ and for $k_{\text {cat }}$ of $7.7 \times 10^{-4} \mathrm{~s}^{-1}$. The unusually high binding constant may be the result of the synergic action and the directional preorganization of the two metallo binding sites ${ }^{24}$ on the calix[4]arene as well as the capacity to adjust the receptor site by low-energy conformational changes of the calix[4]arene moiety. ${ }^{19,25-27}$ As is shown in Figure 1, increase of the $\mathrm{pH}$ to 7.4 results in higher reaction rates and a higher substrate concentration before saturation is reached $\left(K_{\text {assn }}=1.7 \times 10^{4}\right.$ $\left.\mathrm{M}^{-1}, k_{\mathrm{cat}}=10 \times 10^{-4} \mathrm{~s}^{-1}\right)$.

Further analysis of the catalytic activity of 1 yields a bellshaped dependency of the $\mathrm{pH}$ (Figure 2). This behavior ${ }^{6,8} \mathrm{can}$ be explained by opposing $\mathrm{pH}$ effects on catalyst-substrate complex formation $\left(K_{\text {assn }}\right)$ and conversion of the substrate within this complex $\left(k_{\mathrm{cat}}\right)$. Binding of the substrate to the $\mathrm{Zn}(\mathrm{II})$ centers requires the displacement of either a $\mathrm{Zn}(\mathrm{II})$ bound water

(23) The catalytic activity of different calix [4]arene-based dinuclear metal complexes was found to follow the order $\mathrm{Zn}^{2+} \gg \mathrm{Co}^{2+}>\mathrm{Ni}^{2+} \approx \mathrm{Cu}^{2+}$

(24) No saturation kinetics could be observed for mononuclear calix[4]

(25) Grootenhuis, P. D. J.; Kollman, P. A.; Groenen, L. C.; Reinhoudt, D. N.; van Hummel, G. J.; Ugozzoli, F.; Andreetti, G. D. J. Am. Chem. Doc, $1990,112,4165$.

(26) Harada, T.; Rudzinsky, J, M.; Osawa, E.; Shinkai, S. Tetrahedron $1993,49,5941$

(27) Scheerder, J.; Vreekamp, R. H.; Engbersen, J. F. J.; Verboom, W. van Duynhoven, J. P. M.; Reinhoudt, D. N.J. Org. Chem. 1996, 61, 3476

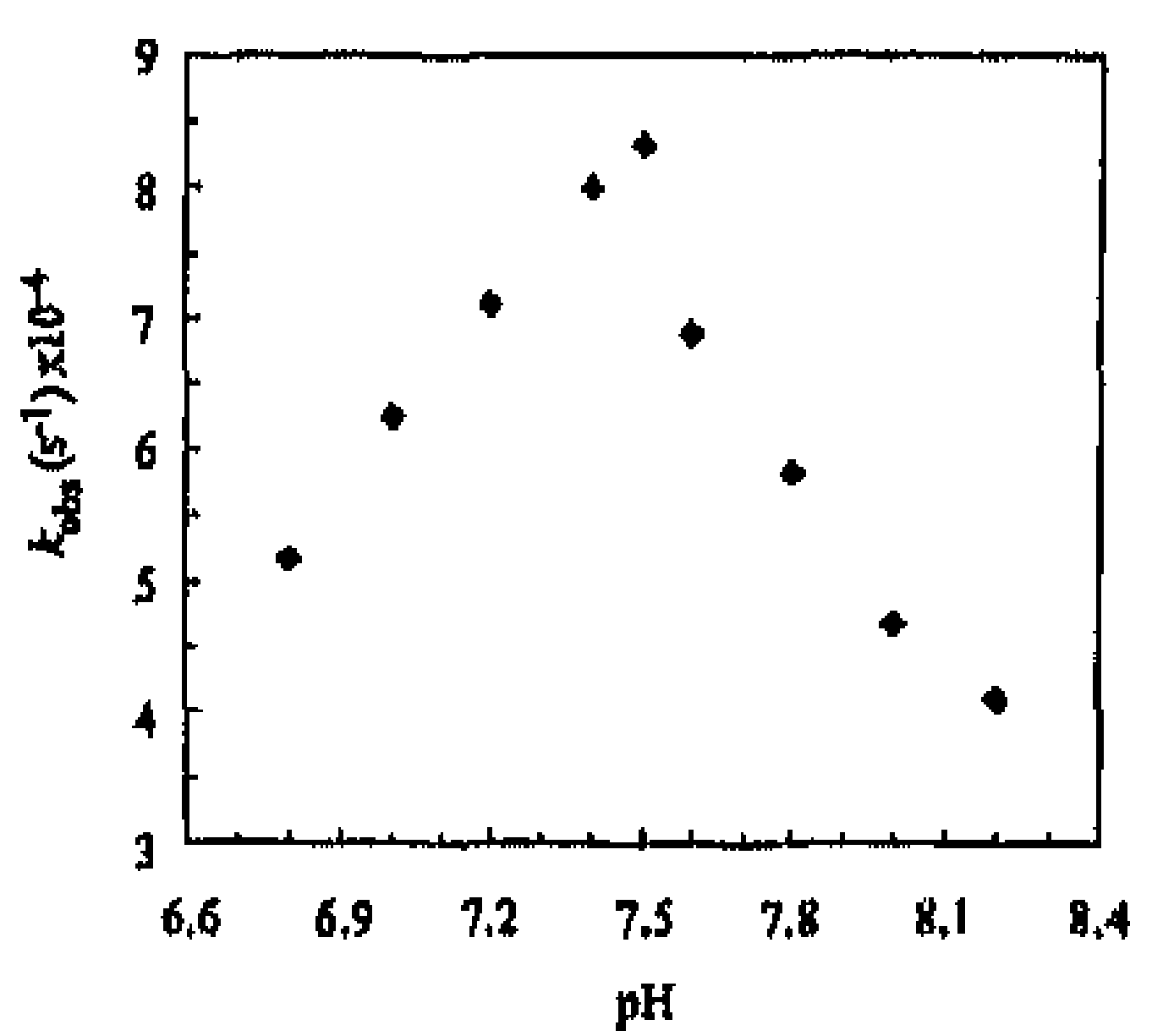

Figure 2. $\mathrm{pH}$ vs rate profile for transesterification of HPNP $(0.19 \mathrm{mM})$ catalyzed by $1(0.48 \mathrm{mM})$ in acetonitrile/20 mM HEPES $1 ; 1(\mathrm{v} / \mathrm{v})$ at $25^{\circ} \mathrm{C}$.

molecule or a more tightly bound hydroxide ion. At higher $\mathrm{pH}$, the fraction of catalyst with $\mathrm{Zn}$ (II) bound hydroxide ions is increased and consequently $K_{\text {assn }}$ decreases. On the other hand, the effective nucleoplile concentration increases due to deprotonation of $\mathrm{Zn}$ (II) bound water molecules (or substrate hydroxyl group), and this increases $k_{\text {cat }}{ }^{28,29}$ The optimum rate at $\mathrm{pH} 7.5$ reveals the relatively low $\mathrm{p} K_{\mathfrak{a}}$ of water coordinated to $\mathrm{Zn}$ (II) in $1{ }^{30}$ which may be due to the close proximity of the hydrophobic calix[4]arene moiety and the presence of $50 \%$ acetonitrile in the reaction mixture. Coates et al, already showed that the $\mathrm{p} K_{\mathrm{a}}$ of water coordinated to $\mathrm{Zn}$ (II) and $\mathrm{Cu}$ (II) is lowered in a hydrophobic environment. ${ }^{31}$

Calix[4]arene 1 is not catalytically active in the hydrolysis of diethyl $p$-nitrophenyl phosphate, etliyl $p$-nitrophenyl phosphate, or $p$-nitrophenyl pliosphate, which shows that the $\beta$-hydroxyl group of HPNP is essential in the catalytic process. Therefore, the most likely mode of catalysis is a bifunctional mechanism in which one of the $\mathrm{Zn}$ (II) centers serves as Lewis acid activator of the phosphate group and the other is involved in activation of the nucleophilic $\beta$-hydroxyl group giving rise to relatively fast intramolecular reaction. ${ }^{8}$

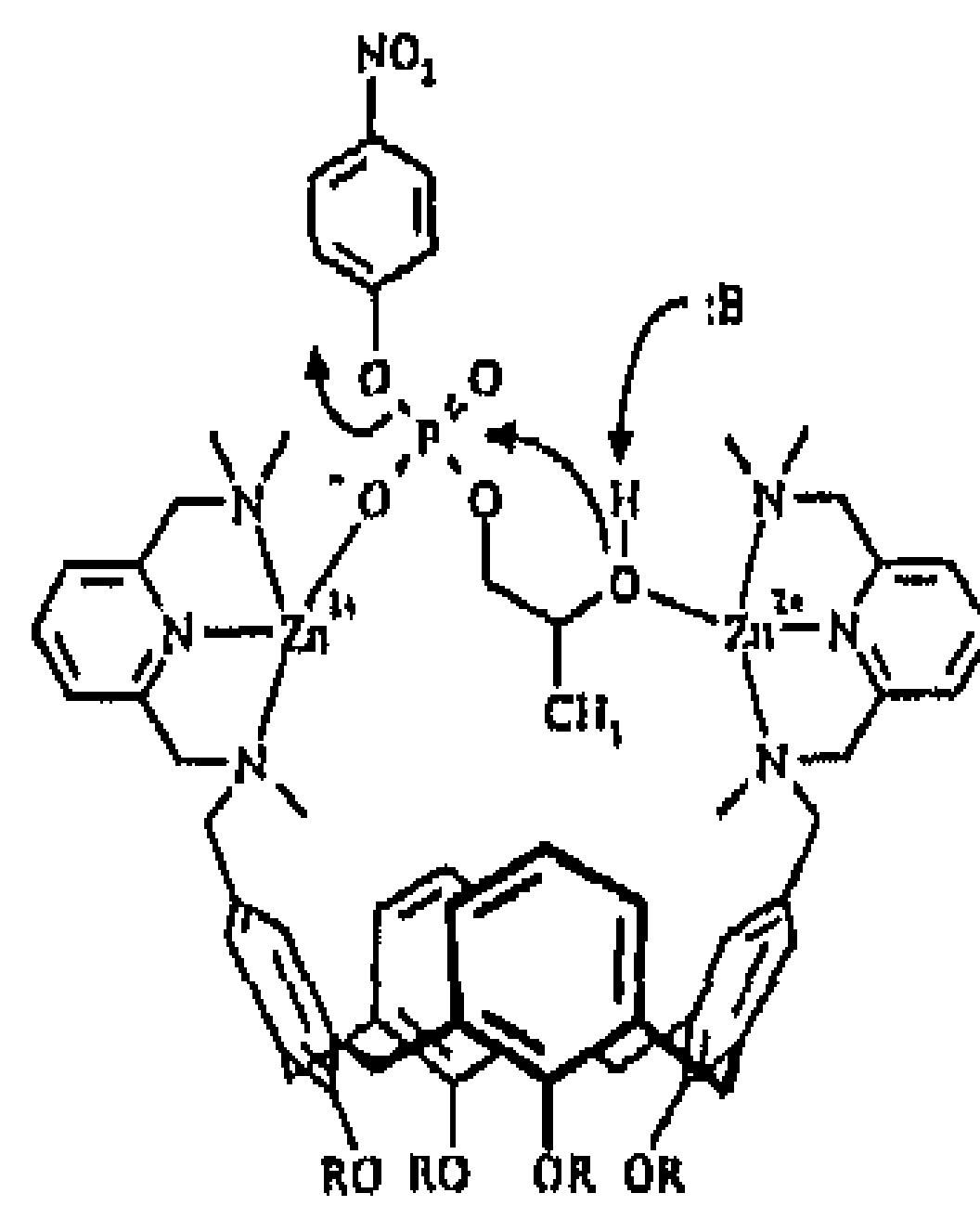

In conclusion, the nuclease mimic 1 , possessing two $\mathrm{Zn}$ (II) centers at the upper rim of a flexible calix[4]arene, exhibits fast and strong binding of HPNP, followed by efficient intramolecular transesterification, overall resulting in fast catalytic turnover under very mild conditions.

Acknowledgment. This investigation was supported by the Netherlands Organization for Scientific Research (NWO) with financial aid from the Netherlands Foundation for Chemical Research (SON).

\section{JA9638770}

(28) Itoh, T.; Fujii, Y.; Tada, T.; Yoshikawa, Y.; Hisada, H. Bull. Chem. Soc. Jpn. 1996, 69, 1265 .

(29) Kimura, E. Progress in Inorganic Chemistry; Karlin, K. D., Ed.; John Wiley \& Sons: New York, 1994; Vol, 41, p 443.

(30) Potentiometric titrations with complex 3 in acetonitrile/ $0.1 \mathrm{mM}$ aqueous $\mathrm{NaClO}_{4} 1: 1(\mathrm{v} / \mathrm{v})$ shows that complex formation, at $\mathrm{pH} 6-8$, is simultaneously followed by the titration of an additional proton in the $\mathrm{pH}$ simultaneously foll
region of $7.5-8.5$.

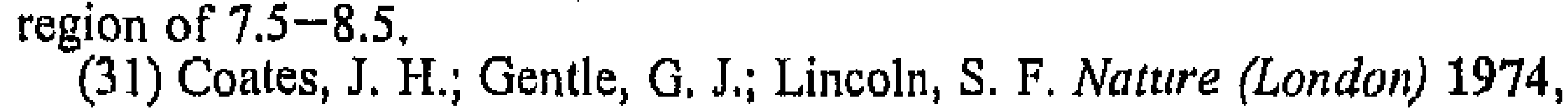
249,773 . 